\title{
Peningkatan Kesadaran Terhadap Hak Cipta Bagi Guru-Guru SMPN 77 Jakarta
}

\author{
Endang Purwaningsih, ${ }^{* 1}$ Evie Rachmawati ${ }^{2}$, Irfan Islami. ${ }^{3}$ \\ ${ }^{1}$ Fakultas Hukum dan Sekolah Pascasarjana Universitas YARSI Jakarta \\ 2\&3 Fakultas Hukum Universitas YARSI, Jakarta \\ *e-mail: e.purwaningsih@yarsi.ac.id. 1.evie.rachmawati@yarsi.ac.id², irfan.islami@yarsi.ac.id³
}

\begin{abstract}
With the condition of the teachers of SMP N 77 Jakarta, they have never received legal counseling on Intellectual Property Rights (IPR) especially Copyright. Knowledge enhancement is expected to motivate teachers to build their self-awareness on IPR to improve competence and ultimately to improve their performance. The solution offered is to provide counseling and training. The method of implementing the applied activities is lecture, discussion and training, with priority on the active participation of teachers. Based on the results of community service, it can be concluded: 1) legal counseling on IPR especially copyright is able to foster awareness of intellectual property so that it is expected to motivate teachers to build awareness of themselves in terms of IPR especially copyright; 2) supporting factors, namely the high desire of teachers to increase intellectual property knowledge, especially copyright.
\end{abstract}

Keywords: awareness, copyright, teacher

\begin{abstract}
Abstrak
Dengan kondisi para guru SMPN 77 Jakarta belum pernah mendapatkan penyuluhan hukum tentang Hak Kekayaan Intelektual (HKI) khususnya Hak Cipta. Peningkatan pengetahuan diharapkan dapat memotivasi guru untuk membangun kesadaran dirinya ber-HKI meningkatkan kompetensi dan akhirnya dapat meningkatkan kinerjanya di SMPN 77 Jakarta Pusat. Solusi yang ditawarkan adalah memberikan penyuluhan dan pelatihan. Metode pelaksanaan kegiatan yang diterapkan adalah ceramah, diskusi dan pelatihan, dengan mengutamakan partisipasi aktif para guru. Berdasarkan hasil pengabdian kepada masyarakat dapat disimpulkan: 1) penyuluhan hukum tentang HKI khususnya hak cipta bagi guru SMPN 77 mampu menumbuhkan kesadaran berkekayaan intelektual sehingga diharapkan dapat memotivasi guru untuk membangun kesadaran dirinya ber-HKI khususnya hak cipta; 2) faktor pendukung yaitu tingginya keinginan guru terhadap peningkatan pengetahuan kekayaan intelektual khususnya hak cipta.
\end{abstract}

Kata kunci: kesadaran, hak cipta, guru

\section{PENDAHULUAN}

Peningkatan kesadaran hukum dapat dilakukan dengan sosialisasi dan edukasi supaya menambah literasi subyek penyuluhan hukum. Pelatihan dilakukan tidak hanya sekedar memberi informasi, akan tetapi juga melatih, memberdayakan, agar para guru SMPN 77 Jakarta memahami apa dan bagaimana hak kekayaan intelektual khususnya hak cipta, akan makin terbuka pengetahuannya, menambah kompetensi dirinya sebagai pencetak generasi terdidik yang lebih unggul. Peningkatan kompetensi guru diharapkan memberi daya dukung bagi meningkatnya kinerja guru. Hasil wawancara dengan Subijakto (2020) Kepala Sekolah SMPN 77 menyatakan bahwa guru SMPN 77 Jakarta berjumlah 35 orang, belum pernah mendapatkan edukasi dan pelatihan HKI hak cipta, sangat bersemangat didukung fasilitas yang memadai di sekolah, untuk membangun kompetensi diri dan mencurahkan dedikasinya untuk sekolah. Bagi SMPN 77, siswa dan guru adalah wahana potensial lahirnya invensi baru, ciptaan baru atau pun kreasi inovatif baru yang mungkin saja layak untuk dihargai kekayaan intelektualnya. 
Guru mempunyai peran yang sangat besar bagi pengembangan sumber daya manusia dalam pembangunan. Untuk melaksanakan peran tersebut, kompetensi guru perlu ditingkatkan dalam kaitannya dengan perlindungan dan promosi hak cipta yang dihasilkan oleh guru. Sebagaimana dikatakan oleh Nikoloski (2017)"It is important to determine what competencies teachers need in order to develop and implement education for sustainable development and to attain specific educational goals with their students." Dalam hal ini, guru dan membutuhkan pengetahuan dan kemampuan untuk menentukan kompetensi apa yang dibutuhkan guru dalam mengembangkan dan mengimplementasikan pendidikan untuk pembangunan sumber daya manusia secara berkelanjutan dan untuk mencapai tujuan pendidikan.

Berdasarkan Pasal 1 Undang-Undang Nomor 14 tahun 2005 tentang Guru dan Dosen, Guru adalah pendidik profesional dengan tugas utama mendidik, mengajar, membimbing, mengarahkan, melatih, menilai, dan mengevaluasi peserta didik pada pendidikan anak usia dini jalur pendidikan formal, pendidikan dasar, dan pendidikan menengah. Pada Pasal 14 UU tersebut disebutkan antara lain hak guru: (1) memperoleh perlindungan dalam melaksanakan tugas dan hak atas kekayaan intelektual; (2) memperoleh kesempatan untuk meningkatkan kompetensi; (3) memperoleh dan memanfaatkan sarana dan prasarana pembelajaran untuk menunjang kelancaran tugas keprofesionalan; (4) memiliki kebebasan dalam memberikan penilaian dan ikut menentukan kelulusan, penghargaan, dan/atau sanksi kepada peserta didik sesuai dengan kaidah pendidikan, kode etik guru, dan peraturan perundang-undangan; dan lain-lain.

Merujuk pernyataan "Teachers have to gain the insight through constructivism, that acquiring competencies is a self-steered and active process, which can be fostered." (Nikoloski, 2017) dalam hal ini, para guru harus mendapatkan wawasan melalui proses konstruksi pengetahuan, bahwa memperoleh kompetensi adalah proses mandiri dan aktif, yang dapat dipupuk.

Guru adalah unsur penting yang menentukan berhasil tidaknya pendidikan. Jika guru berkualitas baik, maka pendidikan pun akan baik. jikalau tindakan para guru dari hari ke hari bertambah baik, maka akan menjadi lebih baik pulalah keadaan dunia pendidikan kita. Sebaliknya, kalau tindakan dari hari ke hari makin memburuk, maka makin parahlah dunia pendidikan kita. Guru-guru kita dapat disamakan dengan pasukan tempur yang menentukan kemenangan atau kekalahan dalam perang (http://menzour.blogspot.com/2016).

Nikoloski (2017) menyimpulkan bahwa, saat ini perlu upaya mempromosikan kesadaran di kalangan guru tentang pentingnya pengembangan kompetensi, khususnya kompetensi guru dalam kaitannya dengan pendidikan untuk pembangunan berkelanjutan

Berkaitan dengan pentingnya kesadaran guru dalam melindungi kreativitas yang selama ini telah dilakukan dalam proses pembelajaran di kelas, di laboratorium, maupun di lapangan, dapat disimak pendapat Weatherley (2014) yang mengatakan bahwa, "There is a need for individuals to appreciate how copyright positively relates to value creation. This report aims to ensure more consumers are made aware of the value of IP. Great work is being done in this arena." Dapat dipahami bahwa, saat ini perlu tumbuh kesadaran bagi guru akan adanya kebutuhan untuk menghargai hak cipta berkaitan dengan penciptaan yang sudah dilakukan. Perlu ada kesadaran akan nilai IP (intellectual property/Kekayaan intelektual). Perlu pekerjaan besar yang lebih cerdas dalam mewujudkan tujuan tersebut khusunya bagi guru.

Weatherley (2014) selanjutnya menyatakan: "The school curriculum needs to prepare pupils of all ages for the 21st century knowledge economy. Interaction with IP is a daily occurrence for many young people. Government and industry must have clear roles in supporting education professionals by developing and delivering online resources, toolkits and lesson plans with and for teachers so that IP finds its way into the curriculum via different subject areas." 
Di sekolah perlu dibangun kesadaran bagi guru dan siswa akan pentingnya pelindungan IP yang dihasilkan. Kurikulum sekolah perlu mempersiapkan siswa dalam menghadapi perkembangan ekonomi dan industri. Interaksi dengan IP adalah kejadian sehari-hari bagi banyak orang muda, sehingga tidak boleh diabaikan dalam sistem pendidikan. Pemerintah dan industri harus memiliki peran yang jelas dalam mendukung para profesional pendidikan sehingga IP dapat dihargai melalui bidang studi yang berbeda-beda.

Berkaitan dengan pentingnya IP bagi guru pernah diteliti oleh Valentino (2015) yang menyatakan: "Faculty members are more likely to share digital copyrighted materials (including online works) with their students, whereas they are more likely to ask permission or guidance when it comes to print materials. Comments from the respondents touch upon issues of the complexity of copyright, and the often time-consuming process of obtaining permissions for the use of copyrighted materials in teaching."

Saat ini, tingkat pemahaman dan kesadaran masyarakat terhadap hukum sangat rendah, sehingga perlu dilakukan peningkatkan baik pada tataran pemahaman maupun ketaatannya. Ardiansah, A., Kadaryanto, B., \& Oktapani, S. (2019) menyatakan bahwa, upaya peningkatan kesadaran dan pemahaman terhadap Undang-undang sangat penting bagi masyarakat, sehingga masyarakat dapat mengetahui hak dan kewajibannya.

Negitu juga menuru pendapat Kamarullah, Nafsiatun, Muhammad Irfani Hendri, \& Ari Widiyantoro. (2019) bahwa kesadaran masyarakan untuk peduli dan memahami hukum atau aturan yang berlaku saat ini sangat penting. Hal itu dapat dilakukan melalui berbagai pelatihan dan sosialisasi.

Yetti, Y., \& Robert Libra. (2018) menyatakan bahwa, tingkat pemahaman masyarakat terhadap undang-undang atau hukum yang sudah berlaku sangat rendah, sehingga perlu ditingkatkan melalui pengabidan kepada masyarakat dalam bentuk sosialisasi maupun melalui seminar.

Zulkarnaen Noerdin, Libra, R., \& Rizana. (2019) menjelaskan bahwa, peningkatan pemahaman masyarakat terhadap undang-undang sangat penting untuk dilakukan. Hal itu dapat ditempuh melalui kegiatan pengabdian kepada masyarakat dan berbagai bentuk sosialisasi lainnya.

Dalam hal ini, tampak kurangnya kesadaran tentang hukum hak cipta dan pedoman penggunaan hak cipta secara adil di lingkungan pendidikan. Sekolah umum tampaknya tidak secara aktif mempromosikan kepatuhan terhadap hak cipta oleh siswa atau guru. Pedoman penggunaan hak cipta tidak dipahami oleh pendidik dan siswa. Berbagai masalah yang memicu pelanggaran kepatuhan hak cipta: (1) kurangnya dana untuk membeli bahan, (2) kurangnya pemahaman tentang manfaat ekonomi dari hak cipta, dan (3) kurangnya kesadaran akan pedoman penggunaan hak cipta secara adil. Meskipun pedoman penggunaan secara adil untuk pendidik dan siswa, masih ada masalah yang belum terselesaikan dalam perlindungan kekayaan intelektual guru dan siswa serta ketersediaan sumber daya gratis dan berkualitas untuk mempromosikan reformasi pendidikan.

Selanjutnya dijelaskan oleh Napper (2008) "There exists an enormous need for free, quality materials for non-profit educational groups. Many free resources are also ones that are not in high demand because they are outdated or not professional prepared." Dapat dipahami bahwa terdapat kebutuhan yang sangat besar akan materi gratis dan berkualitas untuk kelompok pendidikan nirlaba. Banyak sumber daya gratis juga merupakan sumber yang tidak banyak diminati karena sudah usang atau tidak disiapkan secara profesional.

Peneliti lain seperti Rife (2007) menjelaskan bahwa, "The main inquiry explored the relationship between copyright beliefs and teaching practices. Copyright law, particularly fair use, provides broad protection for folks working in education. However, due to participants' lack of 
knowledge and understanding about the law's protections, their ability to share, teach, and have students produce media-rich texts was severely circumscribed. Not only was that, but the researchers found that teachers' lack of knowledge passed on to students as well as colleagues."

Dengan demikian, terdapat hubungan antara kepercayaan hak cipta dan praktik mengajar. Hukum hak cipta, khususnya penggunaan yang adil, memberikan perlindungan luas bagi orangorang yang bekerja di bidang pendidikan, namun karena kurangnya pengetahuan dan pemahaman peserta tentang perlindungan hukum, kemampuan mereka untuk berbagi, mengajar, dan membuat siswa menghasilkan teks yang kaya media sangat dibatasi. Tidak hanya itu, para peneliti menemukan bahwa kurangnya pengetahuan guru yang dapat ditularkan kepada siswa dan juga rekan-rekannya.

Selanjutnya dijelaskan bahwa, "We also want to take it upon ourselves to self-educate on copyright and fair use, and develop accurate and appropriate curriculum. We should make a space for this in our writing programs and professional development seminars." Guru memang layak untuk diangkat dan digali kreativitasnya dengan pelbagai pengayaan materi, agar menambah profesional dan dedikasinya.

Jika mencermati muatan hak kekayaan intelektual, tercantum dalam Trade Related Aspects of Intellectual Property Rights (TRIPs) yang menyebutkan Intellectual Property Rights meliputi: 1) hak cipta (Copyrights) dan hak terkait lainnya yakni hak-hak pelaku (rights of performers), produser rekaman suara dan lembaga penyiaran (producers of soundrecording and broadcasting organizations); 2) merek (Trademarks), 3) indikasi geografis (geographical indications), 4) desain industri (industrial design), 5) paten (patent), 6) desain rangkaian sirkuit terpadu (layout design of integrated circuits), 7) informasi rahasia, rahasia dagang dan data test (undisclosed information, trade secret and test data), dan 8) varietas tanaman baru (new plant varieties)

Terkait materi hak cipta, Jened (2014) menyatakan bahwa hak ekslusif pencipta atau pemegang hak cipta dimaksudkan bahwa tidak ada orang lain yang boleh melakukan hak itu, kecuali dengan ijin pencipta. Menurut civil law system, pelindungan hak cipta memberikan hak ekslusif bagai pencipta yang memberikan kemampuan pencipta untuk berbuat apa saja terhadap ciptaannya, kecuali yang ditentukan dalam aturan pembatasan (limitation). Hak cipta memberikan pelindungan bagi pencipta dalam hubungan pribadi dan intelektual dari ciptaannya dan juga untuk memanfaatkan ciptaannya. Hal ini berarti pelindungan hak cipta berdimensi hak moral (moral right) yang ditimbulkan dari hubungan pribadi dan intelektual pencipta dengan ciptaannya, dan dimensi hak ekonomi (economic right) terkait pemanfaatanya.

Selain pengayaan ilmu HKI khususnya hak cipta kepada guru SMPN 77 Jakarta Pusat, pengusul ingin merangsang dan memacu guru untuk tidak hanya 'diam'sebagai guru yang notabene tersertifikasi, namun lebih inovatif dengan membenahi diri, menambah pengetahuan, dan menggali karya dari ide intelektualitanya, yang mungkin saja bernilai komersil dan dapat diajukan pelindungan kekayaan intelektual, dalam hal ini dibatasi pada materi hak cipta, baik aplikasi maupun penegakan hukumnya. Untuk itulah dengan berbekal sedikit ilmu HKI, pengusul termotivasi untuk berbagi ide demi peningkatan pengetahuan guru SMPN 77 terhadap hak cipta dalam menumbuhkan kesadaran berkekayaan intelektual. Peningkatan pengetahuan diharapkan dapat memotivasi guru untuk membangun kesadaran dirinya meningkatkan kompetensi dan akhirnya dapat meningkatkan kinerjanya di SMPN 77 Jakarta Pusat.

Dari analisis situasi pada pendahuluan di atas, kondisi yang ada saat ini adalah: a) pada umumnya (100\%) para guru SMPN 77 Jakarta belum memahami secara benar tentang Hak Kekayaan Intelektual khususnya Hak Cipta; 2) para guru SMPN 77 Jakarta belum pernah mendapatkan penyuluhan Hak Kekayaan Intelektual khususnya Hak Cipta; dan 3) para guru, khususnya guru SMPN 77 Jakarta kesulitan memperoleh informasi Hak Kekayaan Intelektual umumnya dan khususnya hak cipta. 
Berdasarkan uraian di atas maka dapat disimpulkan bahwa rumusan masalahnya adalah: 1)Bagaimana penyuluhan hukum dapat meningkatkan pengetahuan HKI para guru agar makin sadar hak cipta? 2) Apakah faktor pendukung dan penghambat tumbuhnya kesadaran hukum guru terhadap hak cipta?

\section{METODE}

Tim abdimas mengadakan wawancara awal dengan Kepala SMPN 77 Jakarta tentang kebutuhan yang diinginkan dipelajari lebih mendalam oleh para guru. Diketahui, para guru memerlukan tambahan pengetahuan lebih mendalam mengenai pengetahuan HKI khususnya yang berkaitan dengan hak cipta. Khalayak sasaran kegiatan ini adalah guru-guru SMPN 77 Cempaka Putih Jakarta Pusat sebanyak 35 orang.

Kegiatan ini telah dilaksanakan dengan menggunakan metode berikut:

a. Ceramah dan diskusi

Metode ini digunakan untuk menyampaikan materi penyuluhan yang bersifat kognitif namun

dikemas dengan informasi yang tidak membosankan mengingat guru tetap dalam kondisi

bekerja seperti biasa di kelas. Pelaksanaan metode ini digunakan waktu sebanyak $40 \%$ untuk ceramah atau penyampaian materi, sedangkan sisanya $60 \%$ digunakan untuk diskusi dan tanya jawab.

b. Tanya Jawab/Diskusi

Dalam metode ini, kegiatan utama yang dilaksanakan adalah pembimbingan supaya berpola positive thinking dan memancing peserta untuk berani bertanya dan menyalurkan aspirasi. Dalam metode ini, kegiatan utama yang dilaksanakan adalah pembimbingan dan pelatihan wawasan dan pengetahuan tentang HKI khususnya Hak Cipta. Pada awalnya dilakukan pre test untuk mengungkap pengetahuan para guru secara brainstorming tentang materi HKI khususnya Hak Cipta, kemudian dilakukan pembekalan materi dengan cara sosialisasi dan diskusi, dengan metode ceramah dan latihan. Penyuluhan materi hukum ini dilakukan dengan berbagai materi tentang: 1) wawasan dan pengetahuan tentang HKI secara umum dan 2) wawasan dan pengetahuan tentang hak cipta. Setelah semua materi tersampaikan kemudian dilakukan post test untuk mengetahui tingkat efektivitas kegiatan.

c. Monitoring dan Evaluasi

Terhadap hasil kegiatan ini dilakukan monitoring dan evaluasi dalam waktu 3 bulan kemudian setelah penyuluhan dan pelatihan untuk melihat hasil sesuai dengan perkembangan yang ditargetkan.

\section{HASIL DAN PEMBAHASAN}

Kegiatan telah dilaksanakan dengan baik, dilaksanakan efektif mulai November 2019 hingga Februari 2020 di sekolah SMPN 77 Jakarta. Terjadi peningkatan pengetahuan guru SMPN 77 Jakarta yang signifikan tentang HKI khususnya hak cipta sehingga tumbuh kesadaran berkekayaan intelektual dan diharapkan dapat memotivasi guru untuk membangun kesadaran dirinya meningkatkan kompetensi dan akhirnya dapat meningkatkan kinerjanya di SMPN 77 Jakarta Pusat (62-71\%). Demikian juga diketahui bahwa penyuluhan hukum HKI dapat meningkatkan pengetahuan HKI para guru agar makin sadar berkekayaan intelektual dengan dilakukan secara terprogram, sinergi antara Tim abdimas, Struktural SMP N 77 dan peserta (guru).

Banyak pihak maupun guru yang belum memahami bahwa hak cipta dapat diperoleh tanpa harus mendaftarkan, karena hak cipta bersifat automatic protection. Para penegak hukum seharusnya juga memahami, jangan berpatokan hanya pada "yang tercatat/terdaftar". Biasanya 
dengan dalih untuk menjamin keamanan ciptaannya, seorang pencipta dalam mengeksploitasi (tujuan komersial atau sebagai alat mempermudah pembuktian) akan memilih untuk mendaftarkan/mencatatkan ciptaan ke Direktorat Jenderal Kekayaan Intelektual Departemen Hukum dan HAM. Pendaftaran yang selama ini dikenal, kemudian dalam UU baru (UU nomor 28 tahun 2014) menjadi pencatatan. Beberapa UU baru seperti UU nomor 13 tahun 2016 tentang Paten dan UU nomor 20 tahun 2016 tentang Merek tentu belum dipahami oleh para guru. Konsep economic right dan moral right harus selalu diingat oleh para akademisi.

Guru juga perlu dibuka wawasannya mengetahui overlapping (rancu/tumpang tindih) antara hak cipta dengan hak desain, disebabkan oleh suatu desain misalnya blue print dari penampilan produk tertentu yang termasuk dalam karya seni guna perolehan hak cipta. Jika karya seni dipakai sebagai blue print untuk memproduksi suatu produk maka pemegang karya seni tersebut juga mempunyai hak cipta atas ciptaan karya seninya itu. Misalnya seseorang mendisain sebuah kursi ukir fantastis di atas kertas. Jika desain itu baru dan didaftarkan maka si pencipta desain berhak atas hak desain. Selain itu ciptaan tersebut bisa dinilai sebagai karya seni sehingga bila dia membuat kursi berdasarkan desain tersebut, juga akan memiliki hak cipta atas kursi tersebut (Purwaningsih, 2012).

Terkait proses pembelajaran, guru memegang peran utama, untuk itu guru harus mengetahui terlebih dahulu dan memahami lebih banyak daripada siswanya. Guru perlu diperhatikan, baik dalam kompetensi maupun kinerjanya. Membangun kesadaran hukum adalah bagian dari membangun kehidupan moral bangsa secara keseluruhan yang tidak bisa menunggu sampai kesejahteraan hidup meningkat secara substansial. Pada waktu itu kemungkinan besar kita sudah terlambat (Purwaningsih, 2012).

a. Pemahaman Prinsip Hak Kekayaan Intelektual

Sebelum pelatihan, jumlah guru SMPN 77 yang belum memahami tentang prinsip hak kekayaan intelektual dalam arti hanya mendapatkan skor 3 ke bawah sebanyak 25 orang, akan tetapi setelah pelatihan, jumlah guru yang mendapatkan skor tiga ke bawah hanya 5 orang. Sehingga ada kenaikan kemampuan guru dalam memahami prinsip hak kekayaan intelektual, sebanyak 20 orang (57\%).

\section{Pemahaman prinsip Hak kekayaan Intelektual}

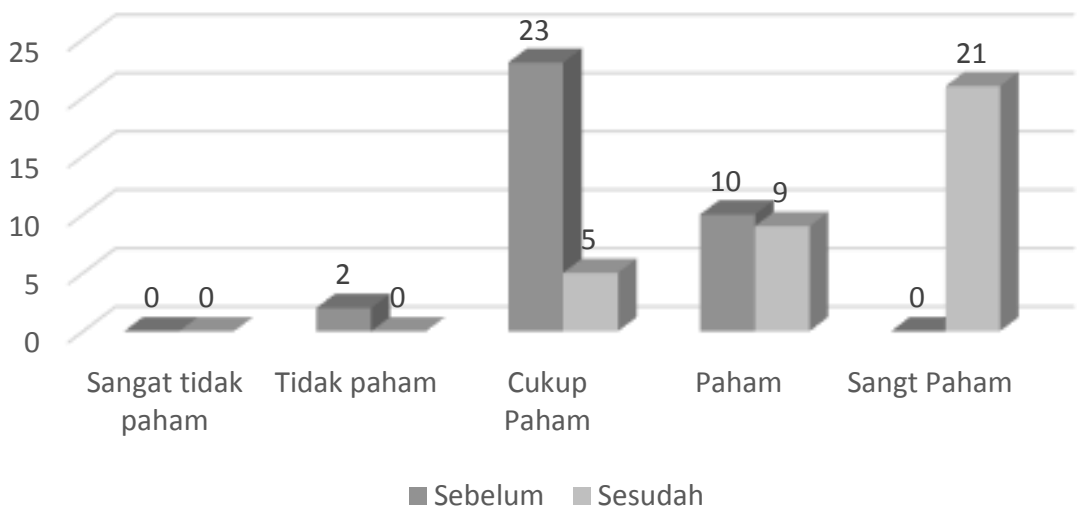

Gambar 1. Pemahaman prinsip Hak kekayaan Intelektual

\section{b. Pemahaman Hak Cipta bersifat Automatic Protection}

Sebelum pelatihan, jumlah guru yang belum memahami tentang Hak Cipta bersifat Automatic Protection bagi guru SMPN 77 dalam arti hanya mendapatkan skor 3 ke bawah sebanyak 25 orang, 
akan tetapi setelah pelatihan, jumlah guru yang mendapatkan skor tiga ke bawah tidak ada seorang pun. Sehingga ada kenaikan kemampuan guru dalam memahami Hak Cipta, sebanyak 25 orang (71).

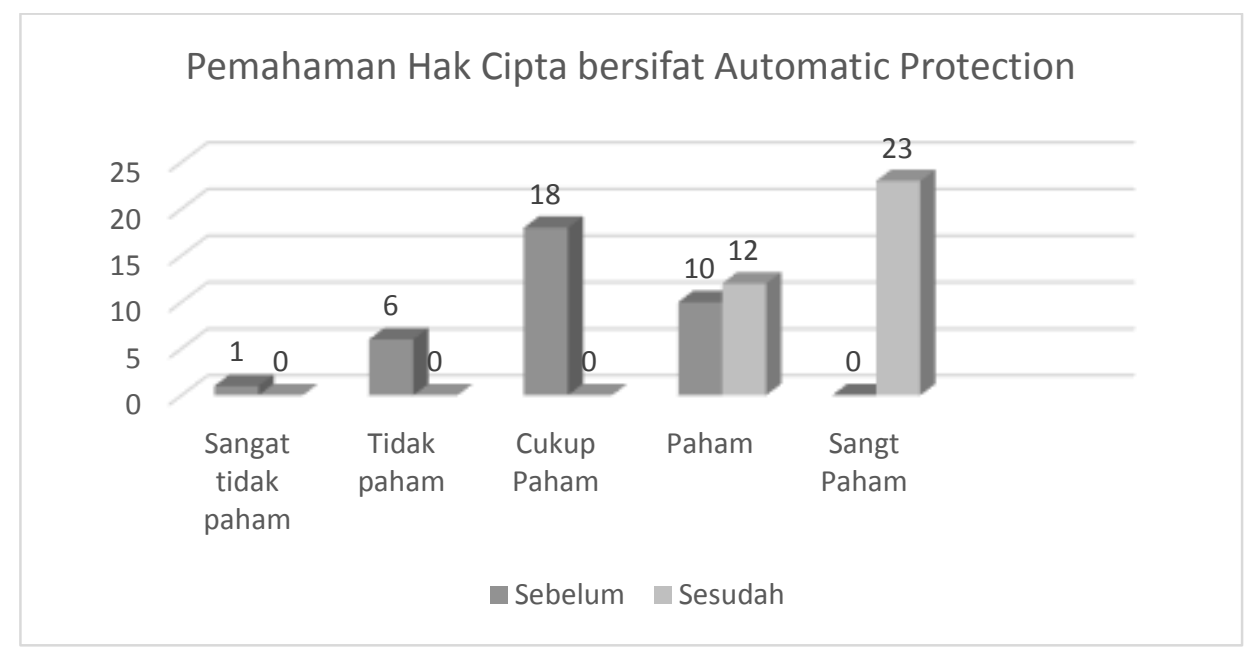

Gambar 2. Pemahaman Hak Cipta bersifat Automatic Protection

\section{c. Pemahaman Syarat dan Cara Perlindungan Ciptaan}

Sebelum pelatihan, jumlah guru yang belum memahami tentang HKI khususnya Syarat dan Cara Perlindungan Ciptaan bagi guru SMPN 77 dalam arti hanya mendapatkan skor 3 ke bawah sebanyak 26 orang, akan tetapi setelah pelatihan, jumlah guru yang mendapatkan skor tiga ke bawah hanya 1 orang. Sehingga ada kenaikan kemampuan guru dalam memahami Syarat dan Cara Perlindungan Ciptaan, sebanyak 25 orang (71\%).

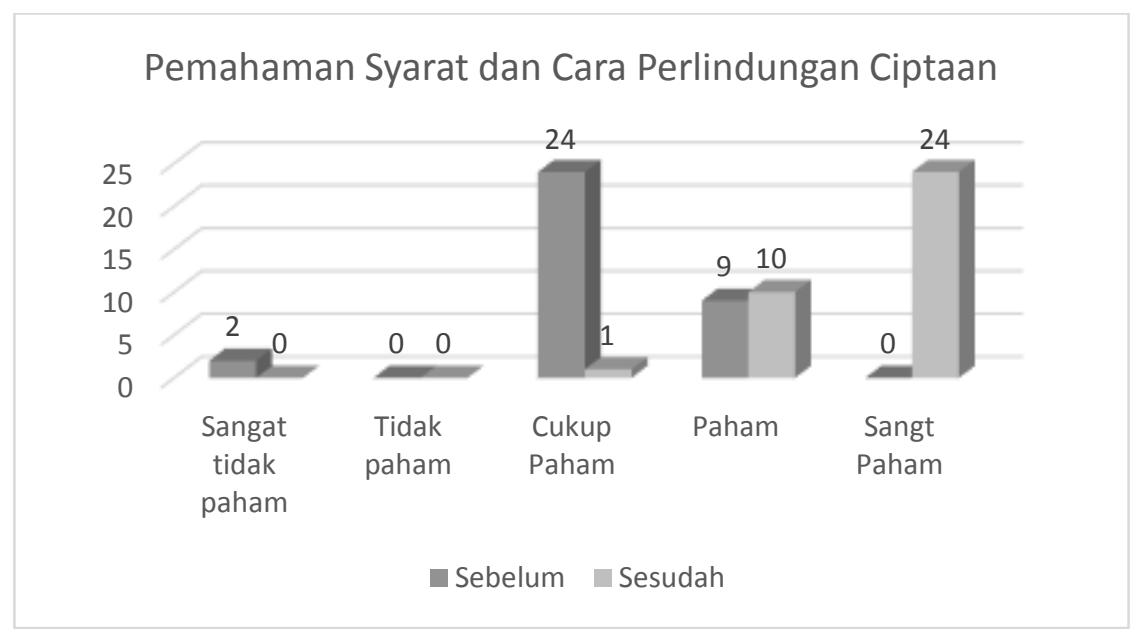

Gambar 3. Pemahaman Syarat dan Cara Perlindungan Ciptaan

d. Pemahaman Obyek dan Subyek Hak Cipta dan pengalihannya, dan periode perlindungan hukumnya.

Sebelum pelatihan, jumlah guru yang belum memahami tentang Obyek dan Subyek Hak Cipta dan pengalihannya, dan periode perlindungan hukumnya. bagi guru SMPN 77 dalam arti hanya 
mendapatkan skor 3 ke bawah sebanyak 24 orang, akan tetapi setelah pelatihan, jumlah guru yang mendapatkan skor tiga ke bawah tidak seorang pun. Sehingga ada kenaikan kemampuan guru dalam memahami Obyek dan Subyek Hak Cipta dan pengalihannya, dan periode perlindungan hukumnya sebanyak 24 orang $(68,5 \%)$.

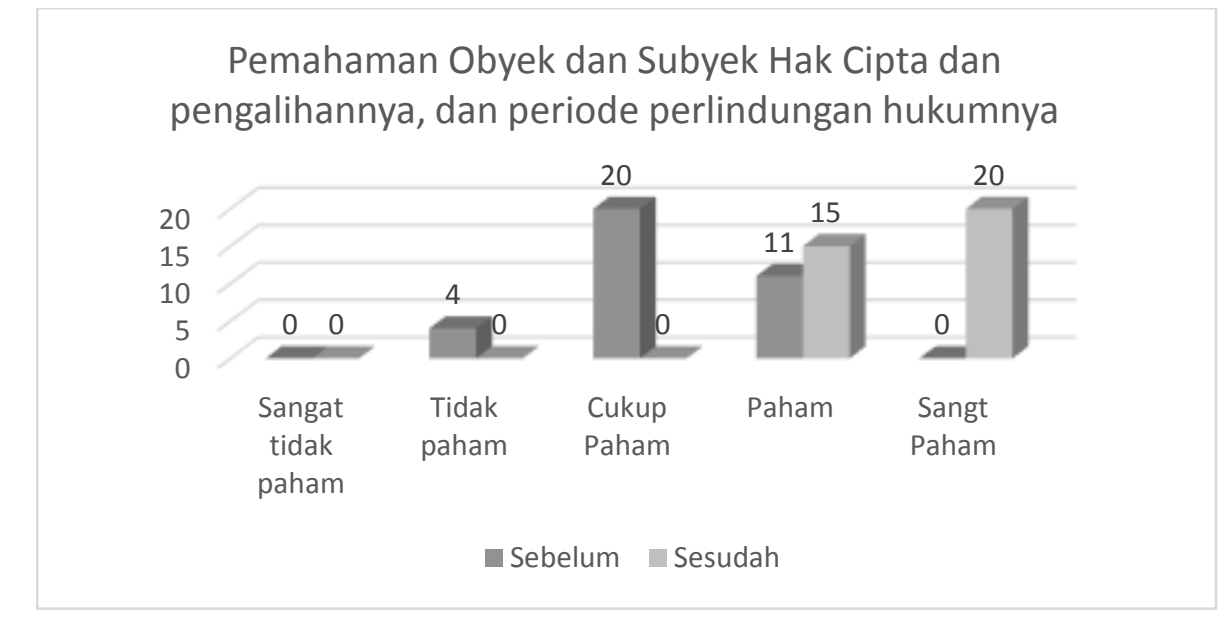

Gambar 4. Pemahaman Obyek dan Subyek Hak Cipta dan pengalihannya, dan periode perlindungan hukumnya.

\section{e. Pemahaman Plagiarisme}

Sebelum pelatihan, jumlah guru yang belum memahami tentang plagiaarisme bagi guru SMPN 77 dalam arti hanya mendapatkan skor 3 ke bawah sebanyak 25 orang, akan tetapi setelah pelatihan, jumlah guru yang mendapatkan skor tiga ke bawah hanya 2 orang. Sehingga ada kenaikan kemampuan guru dalam memahami plagiarisme, sebanyak 23 orang $(65,7 \%)$.

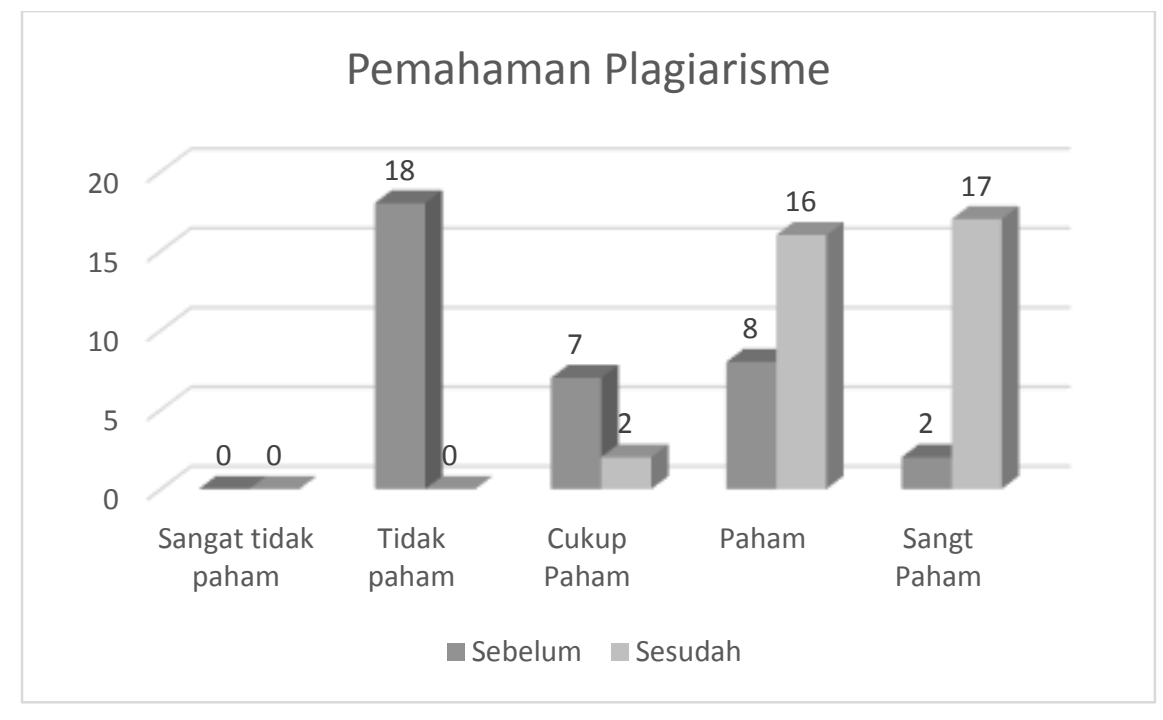

Gambar 5. Pemahaman Plagiarisme 
f. Pemahaman cara pembuatan karya ilmiah dan cara pengutipan yang benar

Sebelum pelatihan, jumlah guru yang belum memahami tentang cara pembuatan karya ilmiah dan cara pengutipan yang benar. bagi guru SMPN 77 dalam arti hanya mendapatkan skor 3 ke bawah sebanyak 25 orang, akan tetapi setelah pelatihan, jumlah guru yang mendapatkan skor tiga ke bawah tidak seorang pun. Sehingga ada kenaikan kemampuan guru dalam memahami cara pembuatan karya ilmiah dan cara pengutipan yang benar, sebanyak 25 orang (71\%).

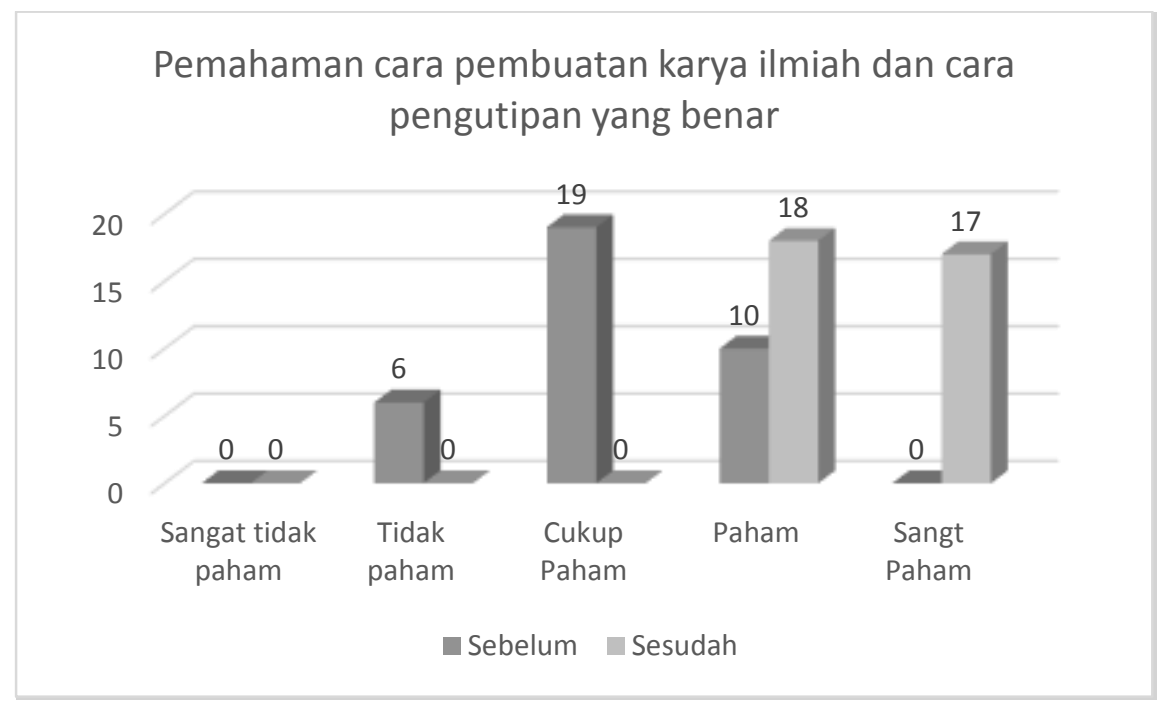

Gambar 6. Pemahaman cara pembuatan karya ilmiah dan cara pengutipan yang benar

\section{g. Pemahaman Delik dalam Hak Cipta}

Sebelum pelatihan, jumlah guru yang belum memahami tentang Delik dalam Hak Cipta bagi guru SMPN 77 dalam arti hanya mendapatkan skor 3 ke bawah sebanyak 23 orang, akan tetapi setelah pelatihan, jumlah guru yang mendapatkan skor tiga ke bawah hanya 1 orang. Sehingga ada kenaikan kemampuan guru dalam memahami Delik dalam Hak Cipta, sebanyak 22 orang (62,8\%).

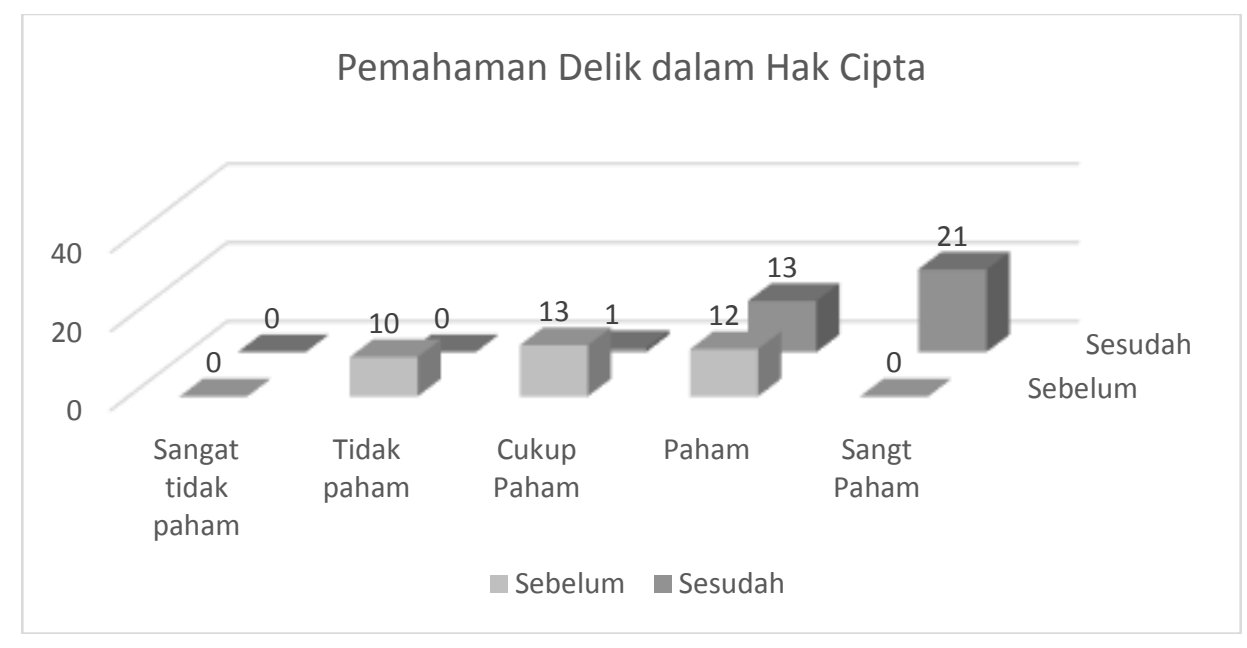

Gambar 7. Pemahaman Delik dalam Hak Cipta 


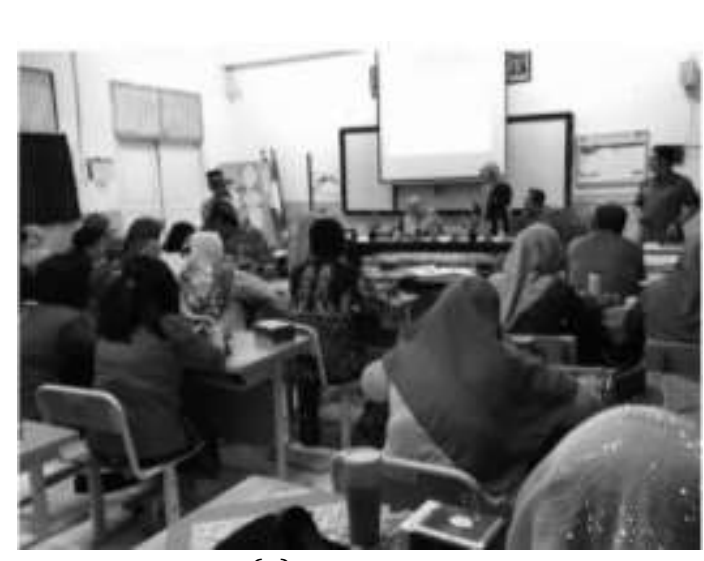

(a)

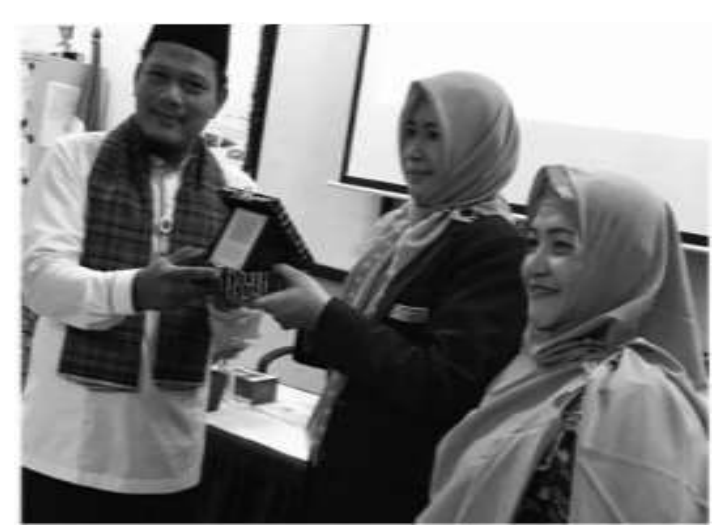

(c)

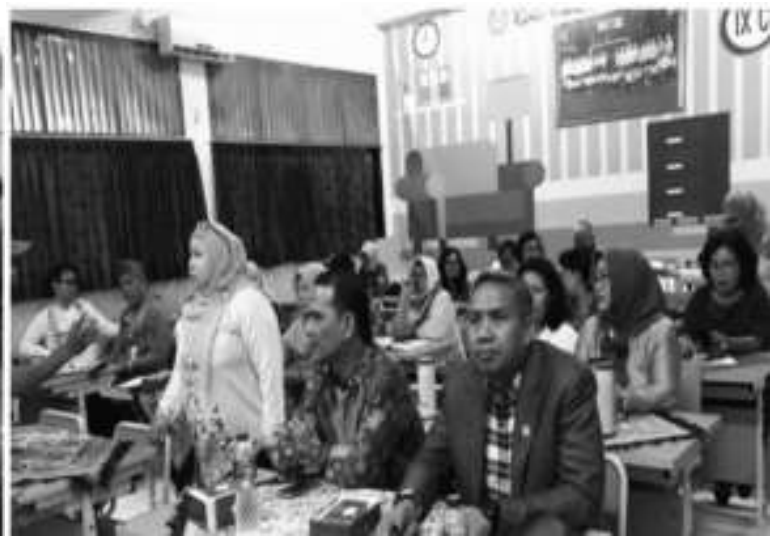

(b)

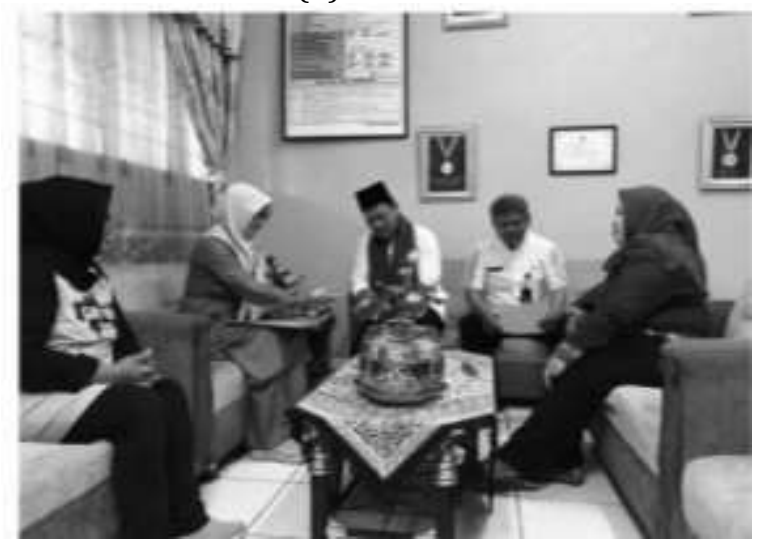

(d)

Gambar 8. (a) Keseriusan peserta saat mengikuti kegiatan, (b) antusias peserta mengikuti kegiatan dan bertanya, (c) Serah terima plakat dan MoU, (d) Wawancara dengan Kepala Sekolah dan Staf

\section{KESIMPULAN}

Kegiatan telah dilaksanakan dengan baik, dan terjadi peningkatan pengetahuan guru SMP N 77 Jakarta yang signifikan tentang transaksi bisnis dalam hukum bisnis dan syariah (60-72\%). Demikian juga:

1. Penyuluhan hukum tentang HKI khususnya hak cipta bagi guru SMPN 77 mampu menumbuhkan kesadaran berkekayaan intelektual sehingga diharapkan dapat memotivasi guru untuk membangun kesadaran dirinya meningkatkan kompetensi dan akhirnya dapat meningkatkan kinerjanya di SMPN 77 Jakarta Pusat;

2. Faktor pendukung yaitu tingginya keinginan guru terkait upaya peningkatan kesadaran berkekayaan intelektual. Penghambat tumbuhnya kesadaran hukum guru terhadap kesadaran berkekayaan intelektual khususnya hak cipta adalah belum adanya pelatihan sejenis yang dilakukan sebelumnya sehingga perlu ditindaklanjuti dengan kegiatan pengabdian lanjut.

\section{UCAPAN TERIMA KASIH}

Terima kasih disampaikan kepada Yayasan, Rektor Universitas YARSI, Wakil Rektor III bidang Pengabdian kepada Masyarakat yang telah memfasilitasi penyelenggaraan kegiatan ini, juga 
penghargaan kepada Kepala Sekolah dan seluruh Guru SMPN 77 yang telah berpartisipasi aktif menjadi khalayak sasaran kegiatan ini.

\section{DAFTAR PUSTAKA}

Ardiansah, A., Kadaryanto, B., \& Oktapani, S. (2019). Penyuluhan Kewajiban Memiliki Ktp-El Di Desa Ujung Batu Timur Kabupaten Rokan Hulu Berdasarkan Undang-Undang Administrasi Kependudukan. Dinamisia: Jurnal Pengabdian Kepada Masyarakat, 2(2), 328-334. https://journal.unilak.ac.id/index.php/dinamisia/article/view/2263

Jened, R. (2014). Hukum Hak Cipta (Copyright Law), Bandung: Citra Aditya Bakti

Kamarullah, N., Hendri, M.I \& Widiyantoro, A. (2019). Peningkatan Perilaku Peduli Hukum Dan Lingkungan Melalui Program Kemitraan Masyarakat Peduli Hukum. Dinamisia: Jurnal Pengabdian Kepada Masyarakat, vol. 3, No. 1, hal: 1-6. https://doi.org/10.31849/dinamisia.v3i1.2056

Menzour. (2016) Menganalisis UU Guru dan Dosen. Accessed: http://menzour.blogspot.com/2016/03/makalah-menganalis-uu-guru-dan-dosen.html

Nikoloski, D. (2017). "The Role of Teachers' Competencies In Education For Sustainable Development." Conference Paper- October 2017. Conference: IBANESS, At Ohrid, Macedonia. Accessed: https://www.researchgate.net/publication/322750996_THE_ROLE_OF_TEACHERS'_COMPETE NCIES_IN_EDUCATION_FOR_SUSTAINABLE_DEVELOPMENT. p.1

Napper, V. S. (2016) Ethical Issues in Copyright Compliance and Fair Use Guidelines in Teacher Education. Weber State University 1304 University Drive Ogden, Utah 84408-1304. p.1. accessed: https://www.academia.edu/18693542/Ethical_Issues_in_Copyright_Compliance_and_Fair_Use_ Guidelines_in_Teacher_Education

Noerdin, Z., Libra, R., \& Rizana. (2019). Peningkatan Pemahaman Personalia PT. Asia Forestama Raya Pekanbaru: Penyelesaian Perselisihan Hubungan Industrial. Dinamisia: Jurnal Pengabdian Kepada Masyarakat, vol. 3. No. 1, hal: 44-49. https://doi.org/10.31849/dinamisia.v3i1.2802

Purwaningsih, E. (2012). HKI dan Lisensi, Bandung: Mandar Maju

Rife, M.C. (2007). The Importance of Understanding and Utilizing Fair Use in Educational Contexts: A Study on Media Literacy and Copyright Confusion. Conference on collage composition and Communication.

Accessed:

https://cccc.ncte.org/cccc/committees/ip/2007developments/copyrightconfusion

Undang-Undang Nomor 28 tahun 2014 tentang Hak Cipta

Undang-Undang Nomor 13 tahun 2016 tentang Paten

Undang-Undang Nomor 20 tahun 2016 tentang Merek

Undang-Undang Nomor 14 tahun 2005 tentang Guru dan Dosen

Valentino, L.D. (2015). "Awareness and Perception of Copyright Among Teaching Faculty at Canadian Universities.”, p.1 FIMS Publications. No. 37. https://ir.lib.uwo.ca/fimspub/37

Weatherley, M. (2014). "Copyright Education and Awareness." A Discussion Paper, Intellectual Property Adviser to the Prime Minister. October 2014, Accessed: http://www.mikeweatherley.com/wpcontent/uploads/2014/10/11.pdf

Yetti, Y., \& Libra, R. (2018). Peningkatan Pemahaman Masyarakat Desa Batang Kulim Kecamatan Pangkalan Kuras Kabupaten Pelalawan Mengenai Undang-Undang Nomor 16 Tahun 2011 Tentang Bantuan Hukum. Dinamisia: Jurnal Pengabdian Kepada Masyarakat, Vol. 2 No. 2, hal: 240246. https://doi.org/10.31849/dinamisia.v2i2.1473 